\title{
Policy shifts, developer contributions and land value capture in London 2005-2017
}

Article

Accepted Version

Creative Commons: Attribution-Noncommercial-No Derivative Works 4.0

McAllister, P., Shepherd, E. and Wyatt, P. (2018) Policy shifts, developer contributions and land value capture in London 2005-2017. Land Use Policy, 78. pp. 316-326. ISSN 02648377 doi: https://doi.org/10.1016/j.landusepol.2018.06.047 Available at https://centaur.reading.ac.uk/77920/

It is advisable to refer to the publisher's version if you intend to cite from the work. See Guidance on citing.

To link to this article DOI: http://dx.doi.org/10.1016/j.landusepol.2018.06.047

Publisher: Elsevier

All outputs in CentAUR are protected by Intellectual Property Rights law, including copyright law. Copyright and IPR is retained by the creators or other copyright holders. Terms and conditions for use of this material are defined in the End User Agreement.

\section{www.reading.ac.uk/centaur}

\section{CentAUR}

Central Archive at the University of Reading

Reading's research outputs online 


\section{Introduction}

Land value capture is a longstanding topic in land policy debates. However, the 'crisis' in housing affordability in London and the south east of England, rising international investment in residential apartments, controversy over the gaming of viability tests by developers and an austerity-driven decline in infrastructure investment, seems to have stirred a renewed interest in the topic. Land value capture refers to mechanisms used to secure societal benefits from increases in land value that can arise from changes to land use rights through the planning system and/or investment in public infrastructure. The term 'betterment' is often used to describe an increase in land value, and a case for taxing betterment is often made in circumstances where land value uplifts are not produced by private investment but are the result of government policy or the value-creating activities of the community.

Ever since the introduction of the modern planning system in 1947, the UK has sought an appropriate means of taxing betterment when privately-owned land is granted new development rights via planning permission. The UK experience is not unique; no betterment tax seems capable of successfully capturing the full uplift from all land owners because the tax is often event-based, usually relying on the action of a landowner to apply for planning permission for development. For instance, Denmark only taxes $50 \%$ of the land value uplift when farmland is re-zoned as urban land. The UK has now abandoned national attempts to tax betterment directly. Instead, an array of instruments act as de facto if not de jure betterment taxes - Stamp Duty Land Tax, local property taxes, capital gains tax, direct development by governmental bodies and localised land value capture through developer contributions. It is the last of these that is the focus of this paper.

In this paper, we examine how the proportion of land value captured through developer contributions in general (and contributions towards non-market housing in particular) has changed, and how policy and market shifts have affected land values and land value capture in inner London between 2005 and 2017. Inner London has been selected as the study area because residential land values have increased dramatically over this period compared to the rest of England. Furthermore, it is in inner London that the housing affordability problem is most acute representing one of the most prominent examples of Wetzstein's “Global Urban Housing Affordability Crisis" (Wetzstein, 2017, 3160). This problem has been exacerbated by changes in government housing policy from 2010 onwards; namely, a reduction in publicly funded non-market housing following the introduction of austerity measures and a relaxation of the policy requirement for developer contributions.

The remainder of the paper is organised as follows. The next section briefly summarises England's current land value capture and non-market housing provision regimes. This is followed by an analysis 
of the changing policy context regarding developer contributions over the study period, and policy changes that have affected the ability of local planning authorities to capture land value uplift. A model of land value change in inner London is presented and the assumptions underpinning the model are discussed. The results of the model are analysed and conclusions are then presented.

\section{Land Value Capture and Non-Market Housing Provision in England}

Contributions from private developers for non-market housing and some other local infrastructure are currently obtained through 'section 106' (S106) agreements. These agreements typically require a developer to make a cash payment or provide an 'in kind' contribution. The latter is often a land contribution or the sale of dwellings to registered not-for-profit housing associations or 'registered providers' of non-market housing at a discounted price. These S106 agreements have been described as "...in effect locally determined and negotiated betterment levies on development values, hypothecated for local needs" (Crook and Monk, 2011, 997). Non-market housing in England is now predominately delivered by the private sector and registered providers.

A new system of land value capture was introduced through the Planning Act 2008: the Community Infrastructure Levy (CIL). CIL came into force in 2010 and provides local government in England and Wales with the opportunity to raise revenue from developers to fund infrastructure CIL can operate alongside a scaled back system of S106 developer contributions. As with S106, CIL is a local levy and it is the responsibility of planning authorities in England and Wales to decide whether to introduce it. ${ }^{1}$ As CIL is non-negotiable, it is S106 developer contributions which may be reduced in circumstances where land value uplifts are small.

Over the last two decades there have been five studies for the Ministry of Housing, Communities and Local Government (or its predecessors) that have attempted to estimate the value of developer contributions (see Crook et al, 2006; Crook et al, 2008; Crook et al, 2010; University of Reading et al, 2014; Lord et al, 2018). Not surprisingly given the timeframe, there are wide variations in the estimated amounts as a result of changing market conditions, policy regimes and changes in relative negotiating power of local planning authorities. In the studies for 2007/8, 2011/12 and 2016/17, affordable housing and land contributions accounted for approximately $70 \%$ of all developer contributions. However, it is notable that in England, it is estimated that in real terms there has been little change in the absolute level of land value capture through planning obligations between 2007/8 and 2016/7. Notably, London alone accounted for $52 \%$ of all affordable units agreed in 2011/12, reducing to $17 \%$ in $2016 / 17$ with the absolute number of units agreed falling from 16,725 to 8,462 . Whilst such figures need to be treated

\footnotetext{
${ }^{1}$ In 2012 the London Mayor introduced a London-wide CIL which is payable in addition to any CIL introduced locally.
} 
with some caution given sampling limitations and the distinction between agreed delivery and units actually delivered, the changing policy context in which these shifts took place is explored below.

\section{The Changing Policy Context 2005 - 2017}

Following the election of the Conservative-led Coalition government in the UK in 2010, the funding and policy environment for non-market housing underwent significant change. The amount of government capital grant funding for the construction of non-market housing was reduced and adjustments to national policy and law were introduced to stimulate the private housing market following the global financial crisis. Reforms were introduced to speed up the planning system and to enable local authorities to grant more planning permissions more quickly. However, while housing delivery was a political priority, the development of non-market homes in particular was not. The 2010 Spending Review announced a significant reduction in funding for non-market housing for the period 2011-2015 (HM Treasury, 2010). The average grant per unit for this funding period equated to $£ 21,920$, down 57\% from the figure for 2008-2011 (Wilcox et al, 2016).

The expectation at the time was that non-market housing secured through S106 agreements would be delivered without any grant (NAO, 2012). This had the potential to reduce the financial viability of housing developments that included market and non-market housing given that the amount which could be paid to developers by registered providers for non-market homes would be likely to decrease ${ }^{2}$. However, it was the intention that removal of grant funding on S106 schemes would be partly compensated for through the introduction of a new non-market housing tenure: affordable rent.

Prior to the introduction of affordable rent, there were two main non-market tenures: social rent and intermediate ownership housing. Social rent housing is let at rents that are established using affordability formulae based on local income levels rather than determined by local market rental levels. Intermediate ownership housing is offered at a price that is below market levels, in both the rental and capital terms, and is offered to occupiers who do not qualify for social rent housing. For intermediate ownership housing, shared ownership and equity loans are offered to those unable to buy a dwelling outright.

Introduced through the Affordable Homes Programme 2011-2015, affordable rent tenure allows registered providers to charge up to $80 \%$ of market rent for leased dwellings (HCA, 2011). It essentially

\footnotetext{
${ }^{2}$ However, as charities, registered providers bidding for S106 homes in London are also able to develop their own private tenure homes and retain the profits to cross-subsidise the provision of low-cost homes elsewhere. Therefore, the reduction in the amounts available to be paid by registered providers in a 'no grant' environment would be mitigated by the option of increasing cross-subsidy spending to compensate for the loss of grant.
} 
replaced "capital grant supply subsidy for social housing with a revenue subsidy" with the subsidy coming from rent-payers rather than the government - although rent payers may also be in receipt of government benefit payments (Wilson and Bate, 2015, 3). The Shared Ownership and Affordable Homes Programme 2016-2021 has pledged grant funding of $£ 7.6$ billion across a six-year period which at an average of circa $£ 1.27$ billion a year is less than half the $£ 2.97$ billion a year average pledged in the 2008-2011 funding period under the previous Labour government (Wilcox et al, 2016 and 2017).

Nevertheless, the introduction of affordable rented tenure has redefined the concept of non-market housing in national policy and law to include tenures which are likely to be less affordable to low income groups. The corresponding decline in the delivery of social rent housing (Table 1) is indicative of this shift in non-market housing priorities.

Table 1: New-build affordable dwelling completions by type of scheme, England

\begin{tabular}{|c|c|c|c|c|c|c|}
\hline & Social Rent & $\begin{array}{c}\text { Affordable } \\
\text { Rent }\end{array}$ & $\begin{array}{c}\text { Intermediate } \\
\text { Rent }\end{array}$ & $\begin{array}{c}\text { Shared } \\
\text { Ownership }\end{array}$ & $\begin{array}{c}\text { Affordable } \\
\text { Home } \\
\text { Ownership }\end{array}$ & Total \\
\hline $2000-01$ & 18,230 &.. &.. &.. & 2,710 & $\mathbf{2 0 , 9 4 0}$ \\
\hline $2001-02$ & 18,640 &.. &.. &.. & 3,100 & $\mathbf{2 1 , 7 4 0}$ \\
\hline $2002-03$ & 17,510 &.. &.. &.. & 3,590 & $\mathbf{2 1 , 1 0 0}$ \\
\hline $2003-04$ & 18,370 &.. & 260 &.. & 5,260 & $\mathbf{2 3 , 8 9 0}$ \\
\hline $2004-05$ & 18,790 &.. & 680 &.. & 7,460 & $\mathbf{2 6 , 9 3 0}$ \\
\hline $2005-06$ & 20,510 &.. & 1,370 &.. & 11,380 & $\mathbf{3 3 , 2 6 0}$ \\
\hline $2006-07$ & 21,440 &.. & 1,110 &.. & 13,680 & $\mathbf{3 6 , 2 2 0}$ \\
\hline $2007-08$ & 25,660 &.. & 1,050 &.. & 17,460 & $\mathbf{4 4 , 1 8 0}$ \\
\hline $2008-09$ & 27,600 &.. & 1,690 &.. & 14,940 & $\mathbf{4 4 , 2 2 0}$ \\
\hline $2009-10$ & 30,400 &.. & 1,910 &.. & 15,750 & $\mathbf{4 8 , 0 6 0}$ \\
\hline $2010-11$ & 35,180 &.. & 2,390 &.. & 15,570 & $\mathbf{5 3 , 1 4 0}$ \\
\hline $2011-12$ & 34,920 & 770 & 1,700 &.. & 15,460 & $\mathbf{5 2 , 8 4 0}$ \\
\hline $2012-13$ & 16,870 & 6,050 & 820 &.. & 15,760 & $\mathbf{3 9 , 5 1 0}$ \\
\hline $2013-14$ & 10,220 & 15,840 & 690 &.. & 9,890 & $\mathbf{3 6 , 6 4 0}$ \\
\hline $2014-15$ & 8,450 & 35,420 & 250 &.. & 14,460 & $\mathbf{5 8 , 5 0 0}$ \\
\hline $2015-16^{P}$ & 5,820 & 14,390 & 1,320 & 4,020 & 3,100 & $\mathbf{2 8 , 6 5 0}$ \\
\hline
\end{tabular}

(Source: DCLG Live Table 1009)

The supply of non-market housing via S106 planning obligations is subject to viability testing. When negotiating the quantity and tenure of non-market housing, planning authorities must ensure that each scheme is financially viable to private sector actors and provides "competitive returns to a willing land owner and willing developer to enable the development to be deliverable" (DCLG, 2012). Further detail setting out "key principles in understanding viability in plan making and decision taking" was added through National Planning Practice Guidance in March 2014 (DCLG, 2014). Financial viability appraisals are frequently submitted by developers to reduce provision of non-market housing. These appraisals, and the assumptions on which they are based, have become contested (Crosby et al, 2013). 
Whilst it is difficult to identify a counterfactual, they are believed to have resulted in lower levels of developer contributions (for example, see Wainwright, 2015).

Policies were also introduced to stimulate the private housing market. The Growth and Infrastructure Act 2013 introduced a new procedure for the modification or discharge of non-market housing requirements secured through S106 agreements. The level of non-market housing was the only type of developer contribution that could be reduced through this mechanism. Reforms were made to liberalise permitted development rights in 2013 so as to enable change of use from office to residential use without the need to obtain planning permission. For projects developed through Permitted Development Rights, no non-market housing needs to be delivered as part of the new development. In contrast, CIL payments are still required from these schemes ${ }^{3}$. In November 2014, the 'vacant building credit' (VBC) and a new nationally applied exemption threshold for non-market housing were introduced (Lewis, 2014). The VBC came in the form of a financial credit "equivalent to the existing gross floorspace of any vacant buildings brought back into any lawful use or demolished for re-development" to be deducted from the calculation of any non-market housing contributions (Lewis, 2014). At the same time a threshold was introduced to address the perceived "disproportionate burden of developer contributions on small scale developers" by exempting sites of then units or less from non-market housing contributions.

The Welfare Reform and Work Act 2016 introduced a requirement for registered providers of nonmarket housing to reduce social housing rents by $1 \%$ a year from April 2016 for a four-year period. The objective of this policy was to "further limit the growth in social housing rents which have been contributing to the rapid growth in the housing benefit bill" in order to "bring rent increases within the social sector back into line with the private rented sector" (DWP, 2015, 1). This four-year stepped reduction in rental income for registered providers could impact the amount providers are able to pay for non-market housing supplied via S106 schemes, potentially threatening future supply of non-market housing. The government hopes that the impact of this will be offset by the "rapid increase in housing association surpluses in recent years" (DWP, 2015: 2). These stood at $£ 3.3$ billion across the sector in 2016 (HCA, 2017).

Taken together, these changes to the policy, legal and funding environment can be interpreted both as pragmatic responses to the fiscal pressures posed by the financial crisis by stimulating the private sector

\footnotetext{
${ }^{3}$ According to London Development Database data, as at July 2017 4,454 new homes (equating to 309,565 sqm) have been consented in inner London as part of schemes of 11 units or more under permitted development rights since the new regulations establishing office to residential permitted change of use were introduced in May 2013. Assuming an average of $25 \%$ affordable housing could have been secured on these schemes prior to the introduction of permitted development rights, this equates to approximately 1,114 'lost' affordable homes (although this does assume that those schemes coming forward under permitted development rights would have come forward anyway which is not a verifiable assumption). Nevertheless, this does illustrate the potential impact of this policy on the supply of affordable housing in inner London.
} 
residential market, as well as policy products that prioritised austerity and promoted development and economic growth at the expense of the delivery of low-cost housing. Below, the implications of these market and policy shift for local land value capture through developer contributions are estimated.

\section{Methodology and Data}

To model land value capture, a means of estimating land value is required. It has long been accepted that urban land values are largely a function of the discounted value of future net incomes obtainable from a site (Hurd, 1903). The standard approach to land valuation has been based on the view that payments for land embody "a residual, equal to the excess of revenues from the sale of goods produced on the land over remunerations to non-land factors used in production." (Mills, 1972, 37). Payments for land are therefore regarded as the residual value remaining after all other factors of production (construction costs, professional fees, developer's return etc.) have been paid at a market level. In US research on land values, this approach was adopted by Davis and Heathcote (2007) and Davis and Palumbo (2008) who model land price changes as a function of the difference between the market value of housing and its replacement costs. In practice, real estate developers typically use the land residual theory to determine the maximum potential value of a site after subtracting all development costs from the total projected development value.

Development costs broadly consist of construction costs, professional fees, brokerage fees, land transfer taxes, developer contributions and a return to the developer, commonly expressed as a percentage of development costs, a margin on development value or as an internal rate of return. Developer contributions include cash payments, requirements to sell a proportion of housing to non-market housing providers at discounted prices and direct provision of in-kind facilities (open space, playgrounds, health care facilities, transport infrastructure etc.). In this context, land value capture essentially represents the difference between what a site would have sold for in a planning regime without developer contributions compared to a planning regime with developer contributions. The monetary amount of land value capture can be expressed as a percentage of land value. This is logical metric if the amount captured is to increase as land value increases. If land value capture is expressed in a different way, as a percentage of units to be developed for example, then, as land values increase, the relative amount of land value capture will fall.

There is no single accepted development appraisal model. Whilst some inputs are relatively straightforward to observe such as sale values and normal construction costs, others such as developer return, finance costs and contingency allowance are more problematic (see McAllister, 2017 for a fuller discussion). As a result, outputs from appraisal models are uncertain and the appearance of precision tends to be spurious. But in the spirit of George Box's argument that all models are wrong and that 
over-elaboration and over-parameterization can signal mediocrity rather than robustness, the purpose here is to try to identify changes in the broad patterns in the distribution of costs, values and returns from residential development in inner London (Box, 1976).

There is a long established yet largely theoretical literature on the welfare effects of land value capture to compensate for negative externalities generated by development, to provide public goods and/or to gain some of the unearned increment in socially generated land value uplifts. This literature has evaluated the effects of developer contributions on allocative efficiency with a focus on the impact of land value capture (through developer contributions) on the quantity and form of development and consumer welfare (see Evans, 1992; Keogh, 1985; Bowers, 1992 and Crook and Whitehead, 2002). However, the conclusions have been inconsistent in terms of the costs and benefits of developer contributions. After evaluating the effects of developer contributions in the form of non-market housing as a quasi-tax using a range of micro-economic models, Crook and Whitehead $(2002,1272)$ concluded that

“...there is a wide range of possible impacts of the 'taxation' policy. If the 'tax' simply transfers economic rent there need be no impact on output, costs, and prices. However, in reality, the situation is likely to be far more complex... The starting point is to demonstrate that landowners do indeed bear the burden of provision in the form of lower land prices. If this can be shown, critics argue that non-market housing represents an effective site-by-site collection of betterment tax (albeit in the form of lower land prices rather than a specific tax levy)."

In the US, a body of empirical work has investigated the costs and benefits of developer contributions (termed impact fees) and their effects on development activity, the values of land and existing real estate assets, distributional issues and the competitiveness of the housing market (see Been 2005 for a comprehensive review of the issues and of empirical work to that date). This work highlights the complex inter-relationships between the house prices of existing dwellings, house prices of new dwellings, local property taxes and development impact fees.

In terms of effects on land values, since it summarises so clearly the assumptions underpinning the land value modelling in this paper, the expected effect on land values of impact fees proposed by EvansCowley, Forgey and Rutherford (2005) is set out below.

"The impact fee is expected to have a negative effect on the value of undeveloped land, while the effect is expected to be positive on developed land. When a property owner sells undeveloped land, the developer will pay less for it because the developer knows that he/she will have to pay the impact fee upon development of the land. Thus, the developer pays a lower price while the seller of undeveloped land receives less money due to the capitalization of the impact fee into the price of the property." (Evans-Cowley et al, 2005, 106) 
However, although their empirical study of 5,425 plots in 43 urban centres in Texas found a small but statistically significant negative effect on land prices, it was not close to the expected "a \$1 development fee impact fee produces a $\$ 1$ reduction in land value" effect (Evans-Cowley et al, 2005). In contrast, using a sample of 1,000 repeat sales in Florida, Ihlanfeldt and Shaughnessy (2004) found that for every $\$ 1$ development impact fee, there was a $\$ 1$ reduction in land value. Also in Florida, in more recent research by Burge (2014), a panel of 1,547,711 residential zoned parcel sales and 134,610 commercially zoned parcel sales was used to measure land prices in hedonic price regressions. Burge (2014) was able to distinguish between development impact fees for education compared to fees for water and sewage infrastructure. It was found that education impact fees have a relatively limited negative impact on land prices and in some model specifications no effect could not be excluded. However, water and sewage infrastructure fees could not be excluded as having a \$1 for $\$ 1$ negative effect on land prices.

These findings highlight that some categories of developer contributions may not necessarily involve a net additional cost to real estate developers. More broadly, most land use regulations have the potential to affect the costs and revenues from a development project which, in turn, affects land prices. For instance, stringent design standards may increase construction costs but may also result in increased sale prices of new dwellings. A proportion of developer contributions will have a positive effect on land values when their cost is more than offset through a positive effect on sale prices. Such developer contributions can then both create and capture land value. Some developer contributions would be expected to have no effect on land prices. Such contributions would be for items where the cost of contribution and its effect on revenue effectively cancel each other out. For instance, cost savings or revenue increases associated with under-provision of open space on a new development may be cancelled out by lower sales prices of new dwellings. Other developer contributions will result in decreased revenues and/or increased costs to the developer. Since affordable housing is usually sold at a discount by the developer, direct affordable housing contributions made either in kind or in cash will reduce the amount that the developer can pay for the land. There is a perception that policy requirements for on-site affordable housing can impact negatively upon sale prices of remaining market dwellings, reducing the potential bid for the land. As we have identified above, the majority of developer contributions have been for affordable housing. In the simulation exercise below, it is assumed that the developer contributions are for affordable housing and other items that, in the absence of a policy requirement, would not have been provided by the developer and thus reduce proportionately the bid price for the land.

To appreciate how the outputs of the land value model should be interpreted, it is important to be explicit about what the model is measuring (and what it is not measuring). Whilst it is a commonly used approach to estimating the value of specific development sites, the model applied in this paper is 
estimating the value that a hypothetical developer would pay for a hypothetical site with a hypothetical scheme in a hypothetical location in an inner London borough with a hypothetical developer contributions regime. In practice, an actual land price outcome will be a product of the idiosyncrasies of an actual site in inner London and the expectations regarding costs and prices of an actual developer for an actual scheme negotiated with an actual planning authority. Therefore, it is not claimed here that the land values generated by the model reflect the values of specific sites. However, we consider the inputs to be reasonable and realistic and the land values to be a plausible indication of the broad patterns and trends for inner London between 2005 and 2017. The remainder of this section summarises the assumptions and inputs underpinning the model.

\section{Development Composition}

Perhaps surprisingly, there is little published data on the level and composition of non-market housing secured through developer contributions. The data used in this study were extracted from the London Development Database (LDD), obtained via a request made under the Freedom of Information Act 2000 on the $8^{\text {th }}$ May $2017^{4}$. The data are aggregated and processed by the Greater London Authority (GLA) based on information supplied by local borough planning authorities. Details of planning permissions approved from the $1^{\text {st }}$ April 2005 onwards are recorded with new permissions added monthly within three months of the end of the month in which they were granted. For the data set we received, the latest recorded planning permission was at the end of February 2017.

Over the 12-year period, planning approval was granted for 4,865 schemes, representing a proposed net gain of 481,286 residential units ${ }^{5}$. The average was nearly 100 units per scheme. These approvals included 190,213 non-market units, 40\% of the total, shown in Table 2. The non-market unit figures in Table 2 include schemes by housing associations and other non-market housing providers, whereas the focus of this research is on non-market units funded through developer contributions from private developers. The database does not record the type of developer so, on the advice of the data compilers, it is assumed that schemes where non-market units constituted more than $50 \%$ of the total number of units were by non-market housing providers and were removed from the analysis. Furthermore, it was assumed that schemes of less than ten units would be exempt from non-market housing contributions, although in practice this would have been at the discretion of local authorities.

\footnotetext{
${ }^{4}$ It should be noted that the LDD is a live database so the data are subject to revision.

${ }^{5}$ All figures relate to the losses and gains associated with the planning permission. Uses within a building or on a site that are unaffected by the permission are not included. Occasionally the data on a permission may not match the information in the development description, particularly when it relates to a phased development. In some instances, existing uses may be spread across multiple permissions. It is also sometimes necessary to split permissions to ensure the net change is measured correctly.
} 
Table 2: Schemes, residential units and non-market units by financial year

(All projects permitted)

\begin{tabular}{|c|c|c|c|c|}
\hline Financial Year & $\begin{array}{c}\text { Number of } \\
\text { schemes }\end{array}$ & $\begin{array}{c}\text { Number of net } \\
\text { residential } \\
\text { units }\end{array}$ & $\begin{array}{c}\text { Number of } \\
\text { non-market } \\
\text { units }\end{array}$ & $\begin{array}{c}\text { \% Non- } \\
\text { market } \\
\text { units }\end{array}$ \\
\hline $2005 / 06$ & 454 & 31,227 & 17,066 & $55 \%$ \\
\hline $2006 / 07$ & 460 & 33,717 & 17,438 & $52 \%$ \\
\hline $2007 / 08$ & 457 & 58,819 & 25,277 & $43 \%$ \\
\hline $2008 / 09$ & 350 & 26,225 & 13,392 & $51 \%$ \\
\hline $2009 / 10$ & 454 & 30,038 & 16,070 & $53 \%$ \\
\hline $2010 / 11$ & 417 & 41,893 & 14,865 & $35 \%$ \\
\hline $2011 / 12$ & 436 & 58,554 & 16,618 & $28 \%$ \\
\hline $2012 / 13$ & 311 & 27,783 & 11,928 & $43 \%$ \\
\hline $2013 / 14$ & 460 & 39,110 & 14,488 & $37 \%$ \\
\hline $2014 / 15$ & 404 & 49,990 & 15,968 & $32 \%$ \\
\hline $2015 / 16$ & 308 & 45,829 & 14,938 & $33 \%$ \\
\hline $2016 / 17$ & 354 & 38,101 & 12,165 & $32 \%$ \\
\hline Total & 4,865 & 481,286 & 190,213 & $40 \%$ \\
\hline
\end{tabular}

Source: Based on data extracted from the London Development Database

The number of schemes and the proportion of average levels of non-market housing are displayed in Table 3. The annual number of projects is small with the average borough granting permission for four to six schemes per annum for majority market housing schemes with more than ten dwellings. Not surprisingly, the low point for approvals (presumably because of a fall in applications) was the financial year 2008-9 following the financial crisis. The change in government in 2010 seems to have been a turning point. Prior to 2010, the proportion of non-market housing secured through developer contributions tended to be slightly above $30 \%$. Since 2010 , this has drifted downwards towards $25 \%$. The most significant shift seems to have been in the composition of the non-market housing rather than overall proportion. Until 2010, approximately $60 \%$ of non-market units were social rented. In 2011, this fell to $44 \%$ and in the following five years it ranged from $42 \%$ to $32 \%$ of the non-market housing component.

All else equal, such a decline in the level and composition of non-market housing would be expected to have had a positive impact on land values. However, development costs, development values and developers' (risk-adjusted) return requirements were also changing during the study period. In addition, the emergence of other developer contribution mechanisms such as the CIL and changes in the nonmarket housing grant regime (and consequently in the prices paid by non-market housing providers for non-market housing units) also changed the expected costs of and revenues from developments projects. These changes would have affected the amount that developers were prepared to pay for sites. 
Table 3: Number of schemes, proportion of non-market and social rented units (excluding permitted projects $<11$ units or $>50 \%$ non-market housing)

\begin{tabular}{|c|c|c|c|}
\hline $\begin{array}{c}\text { Financial } \\
\text { Year }\end{array}$ & $\begin{array}{c}\text { Number of } \\
\text { schemes }\end{array}$ & $\begin{array}{c}\text { Proportion } \\
\text { of non- } \\
\text { market units }\end{array}$ & $\begin{array}{c}\text { Proportion } \\
\text { of social } \\
\text { rented units }\end{array}$ \\
\hline $2005-06$ & 133 & $29 \%$ & $17 \%$ \\
\hline $2006-07$ & 138 & $32 \%$ & $19 \%$ \\
\hline $2007-08$ & 162 & $33 \%$ & $20 \%$ \\
\hline $2008-09$ & 105 & $32 \%$ & $19 \%$ \\
\hline $2009-10$ & 131 & $32 \%$ & $20 \%$ \\
\hline $2010-11$ & 133 & $30 \%$ & $18 \%$ \\
\hline $2011-12$ & 229 & $27 \%$ & $12 \%$ \\
\hline $2012-13$ & 119 & $28 \%$ & $9 \%$ \\
\hline $2013-14$ & 163 & $26 \%$ & $11 \%$ \\
\hline $2014-15$ & 200 & $25 \%$ & $10 \%$ \\
\hline $2015-16$ & 147 & $24 \%$ & $8 \%$ \\
\hline $2016-17$ & 183 & $25 \%$ & $9 \%$ \\
\hline
\end{tabular}

Source: Based on data extracted from the London Development Database

Residential Price and Construction Cost Data

In terms of creating a model of land values in inner London, changes in residential prices were obtained from Office for National Statistics. In March 2005, the average house price in inner London was $£ 254,701$ and had increased to $£ 582,426$ by March 2017. Based on an average dwelling size of 80 square metres ${ }^{6}$, this represents a change in prices from around $£ 3,200$ per square metre in 2005 to $£ 7,300$ per square metre in 2017, nominal house price inflation of approximately $7.5 \%$ per annum. Drawing on the BCIS Tender Price Index for three to five storey residential projects, construction costs increased from $£ 1,100$ per square metre in the first quarter of 2005 to circa $£ 1,550$ per square metre in 2017 , nominal construction cost inflation of approximately $3 \%$ per annum. The trends over time are displayed in Figure 1.

\footnotetext{
${ }^{6}$ This figure is cited in Housing in London 2015: The Evidence Base for the Mayor's Housing Strategy.
} 
Figure 1: Land value determinants: key indicators

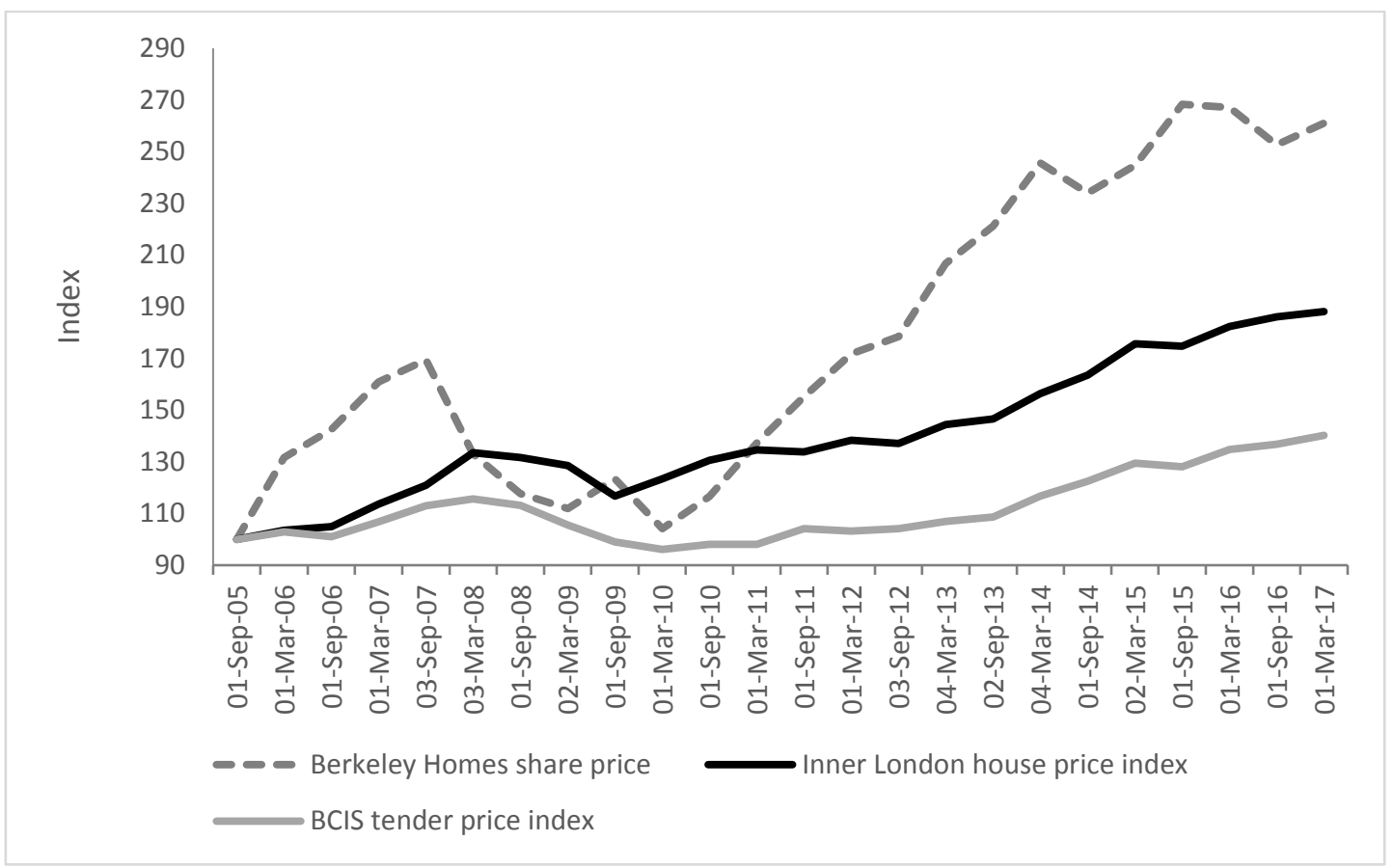

All else equal, such differences in cost and value inflation rates would be expected to lead to higher land value growth. For instance, in an area where site value constitutes $10 \%$ of the house value, if house price inflation exceeded building cost inflation by $1 \%$, land values would go up by approximately $10 \%$. However, if site value constitutes a higher proportion of the house value, then land price inflation and house price inflation would be much closer together. The magnitude of the effect depends on the initial ratio of building costs to site value - the higher the ratio, the bigger the effect. In our model, in 2005, after construction costs, the typical site would be expected to generate a surplus of $£ 2,100$ per square metre of new development to pay for land, additional development costs, developer contributions and developers' return. By 2017, the corresponding figure is estimated at $£ 5,750$ per square metre of new development (a growth rate of approximately $10 \%$ per annum). To estimate land values more robustly, a range of assumptions have been made about other development costs, including developer contributions.

\section{Density, Developer Profit and Other Development Costs}

The output from a development appraisal (usually an estimate of land value or developers' return) can be very sensitive to changes in appraisal inputs, most of which are prone to a degree of uncertainty. Sale values and construction costs are particularly important since many of the other inputs are expressed as ratios of them. Some of the ratios are factual - Stamp Duty Land Tax for example - whilst others are estimates such as required profit, contingency and finance costs. In terms of modelling land value estimates, commonly used assumptions regarding these ratios have been made, drawing upon CIL 
development viability studies that are in the public domain. Density estimates have been derived from an analysis of the project level data in the London Development Database. This has remained reasonably stable, oscillating around 2.8 square metres of residential development per square metre of site area.

A return to the developer has been assumed as a profit margin of $20 \%$ of the value of the project assuming no non-market housing. This is likely to be higher than typical. However, any additional profit can be assumed to act as a surplus to account for potentially omitted cost inputs. Empirically, $20 \%$ of Gross Development Value has been accepted in viability studies submitted for planning purposes. However, Crosby and Wyatt (2017) find a range of metrics in sites subject to planning appeals. In practice, profit margins for development projects are difficult to robustly evaluate and justify. They are likely to vary over time, between projects/locations and between developers. Ultimately, the perceived levels of project and market risk are going to be the main determinants. Market risk will be determined by the interaction of local and macro-economic performance and the capital markets and project risk will be determined by any factors including nature of site, planning status, size and complexity of scheme.

Notwithstanding the above points, the $20 \%$ profit margin has been adjusted to reflect variations in risk over the cycle. In periods when house prices are falling or flat and the share price of a London-focussed residential development company (Berkeley Homes) falls in the preceding six months, the expected profit margin is increased to $22.5 \%$. This occurs in two periods. The first was the period following the financial crisis when the average inner London house price fell from $£ 4,295$ per square metre in September 2007 to $£ 3,603$ in March 2009 and Berkeley Homes’ share price fell from $£ 16.35$ in March 2007 to $£ 7.47$ in March 2010. The second was September 2016 following the EU referendum result in June of that year. Required profit margins were also reduced to $17.5 \%$ in two periods: before the financial crisis, when Berkeley Homes' share price approximately doubled between September 2005 and September 2007 and house prices in inner London rose by more than 10\% per annum; and in the period 2013 to 2014.

\section{Developer Contributions}

The key remaining assumptions concern the amount of developer contributions during the study period. As discussed above, we draw upon the London Development Database data to estimate the proportion and tenure composition of non-market housing. Prices paid by non-market housing providers over the study period are more problematic. In various reports for inner London boroughs commissioned for policy formation, assumptions about prices paid for non-market housing tend to be based on grant availability, assumed rental receipts and (for intermediate tenure) discount to Market Value. 
Since 2011, grant funding for non-market housing has been greatly reduced. Post-2010 viability studies for private developers invariably assume nil grant. In contrast, grants of $£ 20,000-£ 30,000$ per person housed were common before the change of government in 2010. Whilst it is risky to generalise, in some inner London boroughs, S106 planning agreements set out the rents that can be charged for non-market units and/or specify the discount to Market Value that they should be sold to non-market housing providers. Policies regarding rents for the various tenures are then guided by a blend of national and Mayoral policies and interpreted and implemented at the local borough level. Broadly, the trend has been for larger discounts to Market Value in period since 2010. Based on an analysis of viability studies from inner London boroughs (see Appendix 1), a broad assumption is made in the land value model that, for each non-market dwelling, developers could expect to receive 50\% of the Market Value of a market dwelling in the period prior to 2010, falling to 30\% of Market Value after 2010.

However, it should be acknowledged that the estimation of this variable poses significant challenges. The amount of revenue reduction experienced by developers due to non-market housing requirements varies between tenure and the level of market value. Both are affected by policy and market volatility. Residential market values can vary sharply over time and vary by three or fourfold within a borough at any given point in time. Given much lower cross-sectional and temporal variation in the prices that non-market housing providers can pay to developers, percentage discounts to market values will be variable across time and place. Nevertheless, we consider that our assumed discount levels broadly reflect the overall trend over the study period.

\section{Results}

Before presenting the findings for the whole period, in order to provide a clear illustration of how the land values are estimated, the model outputs are presented for September 2005 and March 2017. Two scenarios are presented for both periods. Scenario 1 shows land value estimates assuming developer contributions based on the contemporaneous policy environment, and scenario 2 shows land value estimates assuming no developer contributions. It is assumed that, in scenario 2 , other revenue and cost variables are unaffected by the assumed absence of developer contributions.

In September 2005, based on the average house price of $£ 3,145$ per square metre (incorporating an assumption of $2.5 \%$ sale fees) and a plot ratio of 2.8 , the hypothetical site is expected to generate $£ 8,806$ revenue per square metre of site area assuming no developer contributions. Total development 


\section{September 2005 estimates}

Plot ratio

Market Value of dwelling ( $f$ psm of project NIA)

Revenue ( $\mathrm{f}$ psm of site area assuming no developer contributions)

Construction costs ( $f$ psm of project GIA)

Construction costs ( $\mathrm{f}$ psm of site area)

Abnormal costs ( $f$ psm of site area)

Professional fees ( $£$ psm of site area)

Developer profit (20\% of revenue with no non-market housing)

Other 106 costs ( $f$ psm of site area)

Commuted payment for non-market housing ( $f$

psm of site area)

Non-market housing revenue impact ( $\mathrm{f}$ psm of site area)

Total development costs $£$ psm of site area

Land value $f$ psm of site area (gross of costs)

Land value $€$ psm of site area (net of costs)

\section{March 2017 estimates}

Plot ratio

Market Value of dwelling ( $f$ psm of project NIA)

Revenue ( $£$ psm of site area assuming no non-market housing)

Construction costs ( $f$ psm of project GIA)

Construction costs ( $f$ psm of site area)

Abnormal costs ( $f$ psm of site area)

Professional fees ( $f$ psm of site area)

Developer profit (20\% of revenue with no non-market housing)

Other s106 costs and local CIL ( $f$ psm of site

area)

Commuted payment for non-market

housing ( $f$ psm of site area)

Non-market housing revenue impact ( $f$ psm of site area)

Mayoral CIL ( $\mathrm{f}$ psm of site area)

Total development costs $£$ psm of site area

Land value $f$ psm of site area (gross of costs)

Land value $\mathrm{f}$ psm of site area (net of costs)

$\begin{array}{cc}\text { Scenario } 1 & \text { Scenario } 2 \\ \text { Planning } & \text { No planning } \\ \text { obligations } & \text { obligations }\end{array}$

$2.8 \quad 2.8$

$£ 3,145$

$£ 3,145$

$£ 8,806$

$£ 8,806$

$\begin{array}{cc}£ 1,262 & £ 1,262 \\ £ 3,534 & £ 3,534 \\ £ 442 & £ 442 \\ £ 398 & £ 398 \\ £ 1,761 & £ 1,761 \\ £ 395 & £ 0\end{array}$

$£ 70 \quad £ 0$

$£ 1,409 \quad £ 0$

$£ 8,008 \quad £ 6,134$

\begin{tabular}{|ll|}
$£ 798$ & $£ 2,672$ \\
\hline$£ 754$ & $£ 2,525$ \\
\hline
\end{tabular}

$£ 6,950$

$£ 19,460$

$£ 19,460$

$\begin{array}{cc}£ 1,844 & £ 1,844 \\ £ 5,163 & £ 5,163 \\ £ 645 & £ 645 \\ £ 581 & £ 581 \\ £ 3,892 & £ 3,892\end{array}$

$£ 395 \quad £ 0$

$£ 420 \quad £ 0$

$£ 3,406 \quad £ 0$

f112 f0

$£ 14,614 \quad £ 10,281$

$£ 4,846 \quad £ 9,179$

$£ 4,538 \quad £ 8,675$ 
costs, excluding the costs of land acquisition, are estimated to be $£ 8,008$ per square metre, approximately a quarter of which are developer contributions ( $£ 1,874$ per square metre $\left.{ }^{7}\right)$. Representing c $8.5 \%$ of the value of the completed scheme, a site value of $£ 754$ per square metre is estimated.

Whilst land values will be sensitive to values in local sub-markets, local planning policies and site conditions, this figure seems plausible and is broadly consistent with the UK government Valuation Office Agency’s estimates for inner and outer London of $£ 702$ per square metre of residential land in July 2005 and $£ 727$ per square metre in January 2006. The value of the site assuming no developer contributions is estimated to be $£ 2,525$ per square metre. Hence, it is estimated that developer contributions capture $71 \%$ of the zero developer contribution (Scenario 2) site value ${ }^{8}$.

As discussed above, by March 2017 house prices and construction costs had changed significantly over the 12 -year period; by $220 \%$ and $146 \%$ respectively. These revised inputs lead to a site value of $£ 4,538$ per square metre, approximately $23 \%$ of the value of the scheme and representing an increase in land value of approximately $600 \%$ since 2005 . Again, this land value estimate seems plausible and site sales in inner London boroughs such as Southwark and Camden support this estimate. The Greater London Authority (2016) presents estimates of residential land values for 2015 of $£ 33.3$ million per hectare in Camden, $£ 52.0$ million per hectare in Islington and $£ 41.1$ million per hectare in Southwark. The modelled land value estimate for September 2015 is close to $£ 45$ million per hectare.

For March 2017, total development costs excluding the costs of land acquisition are assumed to be $£ 14,614$ per square metre of site area. The total cost of developer contributions is estimated to be $£ 4,333$ per square metre of site area, most of which (nearly 88\%) reflect the impact of non-market housing provision ${ }^{9}$. The value of the site in the absence of developer contributions is estimated to be $£ 8,675$ per square metre. Hence, it is estimated that developer contributions capture c $49 \%$ of the site value in the no developer contributions scenario.

\footnotetext{
${ }^{7} 75 \%$ of the developer contributions represent the reduction in revenue from providing affordable rather than market housing, based on the assumption that $32 \%$ of the development is sold to a non-market housing provider at a discount of $50 \%$ from Market Value ( $£ 8,806 * 0.5 * 0.32)$.

${ }^{8}$ Note that this is not an estimate of amount of land value uplift that was captured. The proportion of the uplift tends to be slightly higher. In 2009, industrial land was estimated at approximately $£ 2$ million per hectare in Southwark and Islington/Hackney. Using broadly this estimate of existing use value, in September 2009 the model estimates land value capture at 57\% (of the zero developer contribution land value) and land value uplift capture is estimated at $61 \%$ (of the difference between the existing use value and the zero developer contribution land value). This difference is typical.

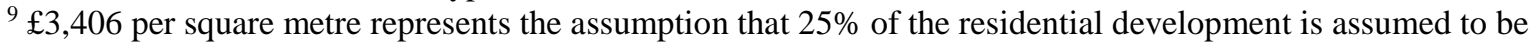
sold to a non-market housing provider at a discount of $70 \%(£ 19,460 * 0.7 * 0.25)$ and that a commuted payment is $£ 420$ per square metre of site area is made
} 
The trends in estimated land value over the study period are presented in Figure 2. Largely driven by house price growth of $10 \%$ and $21 \%$ in 2006 and 2007, there is a sharp jump in the estimated land value

Figure 2: Inner London land value growth in context: 2005-2017

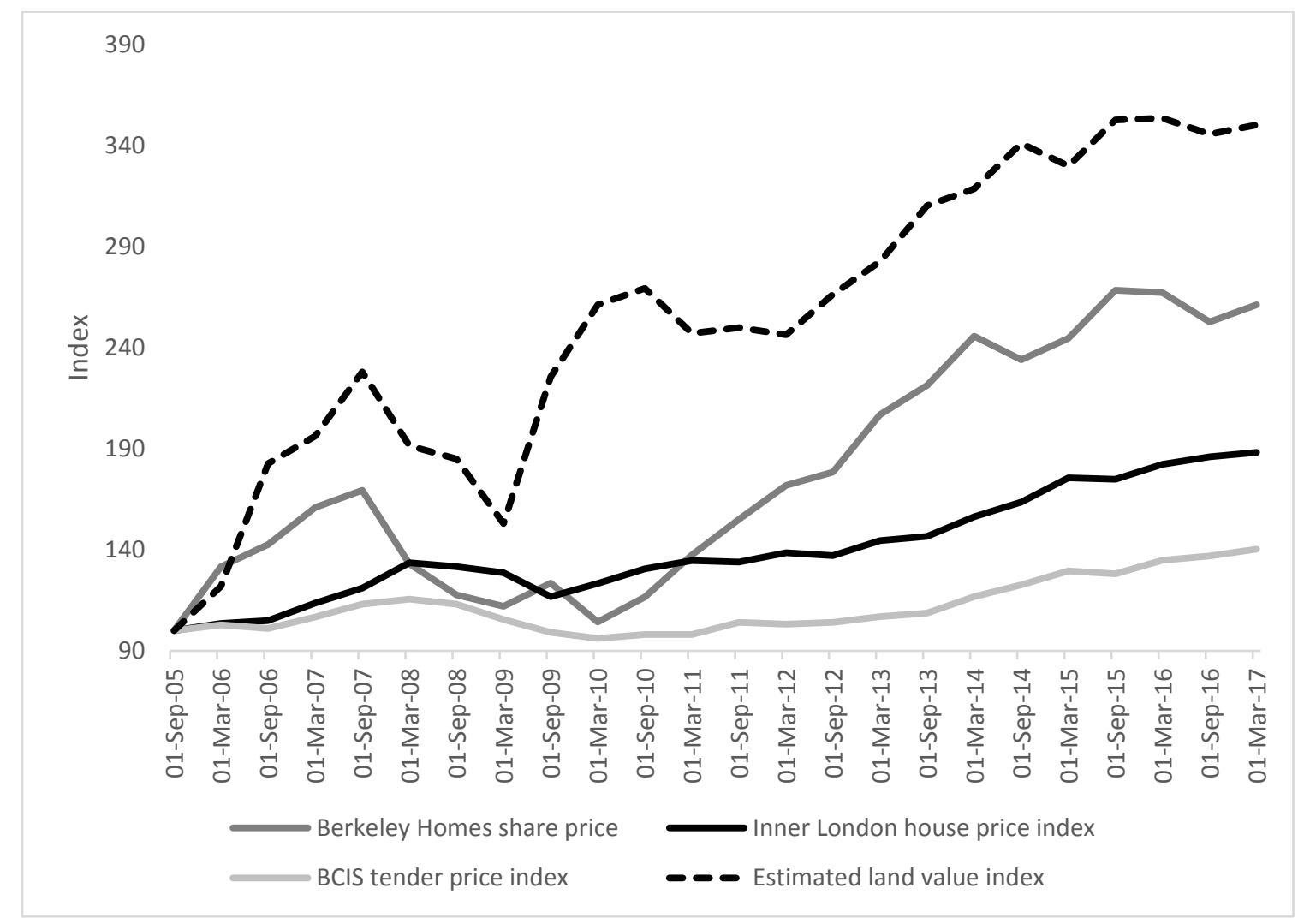

Figure 3: Trends in estimated land value and land value capture 2005-2017 


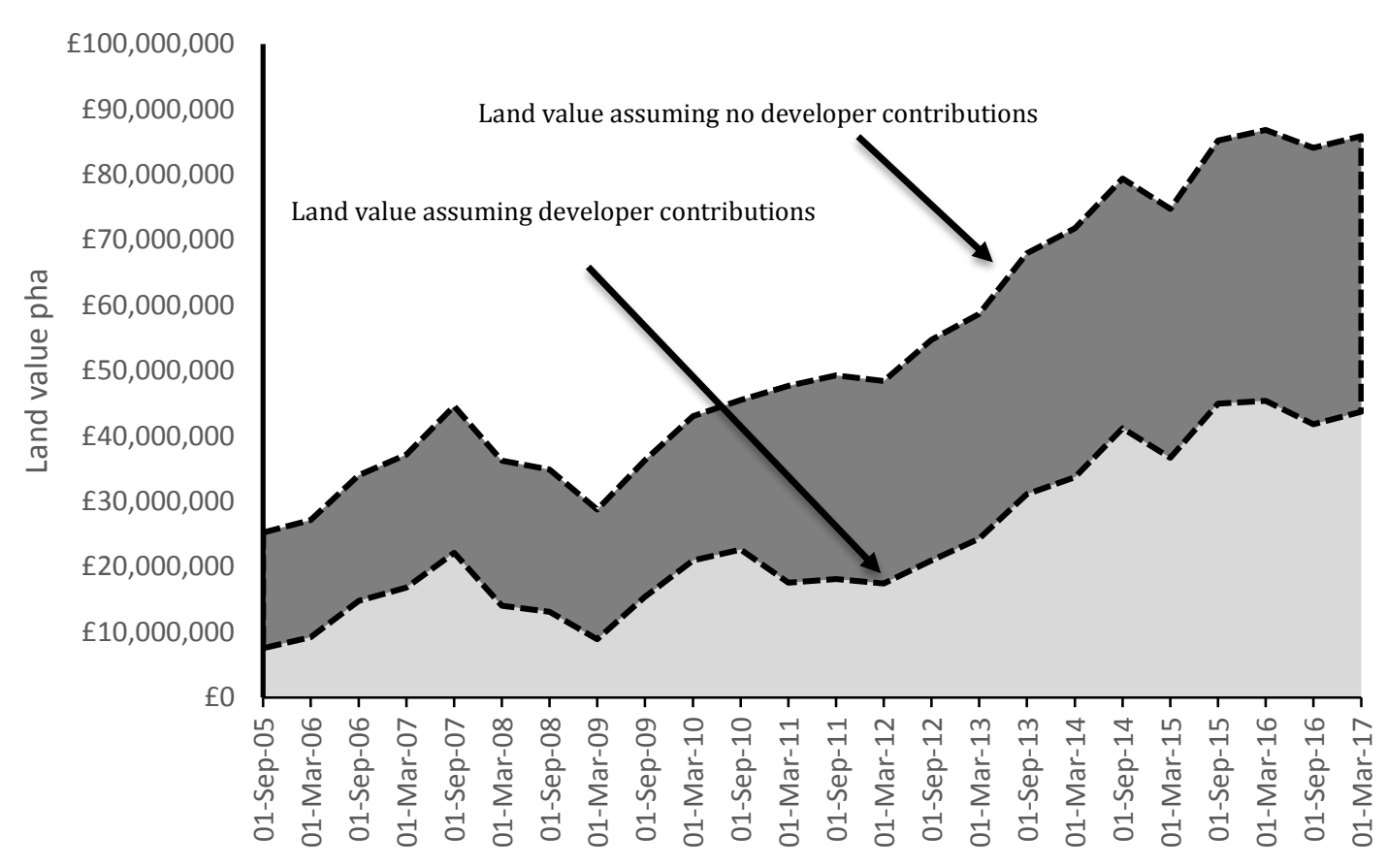

Figure 4: Trends in land value capture 2005-2017

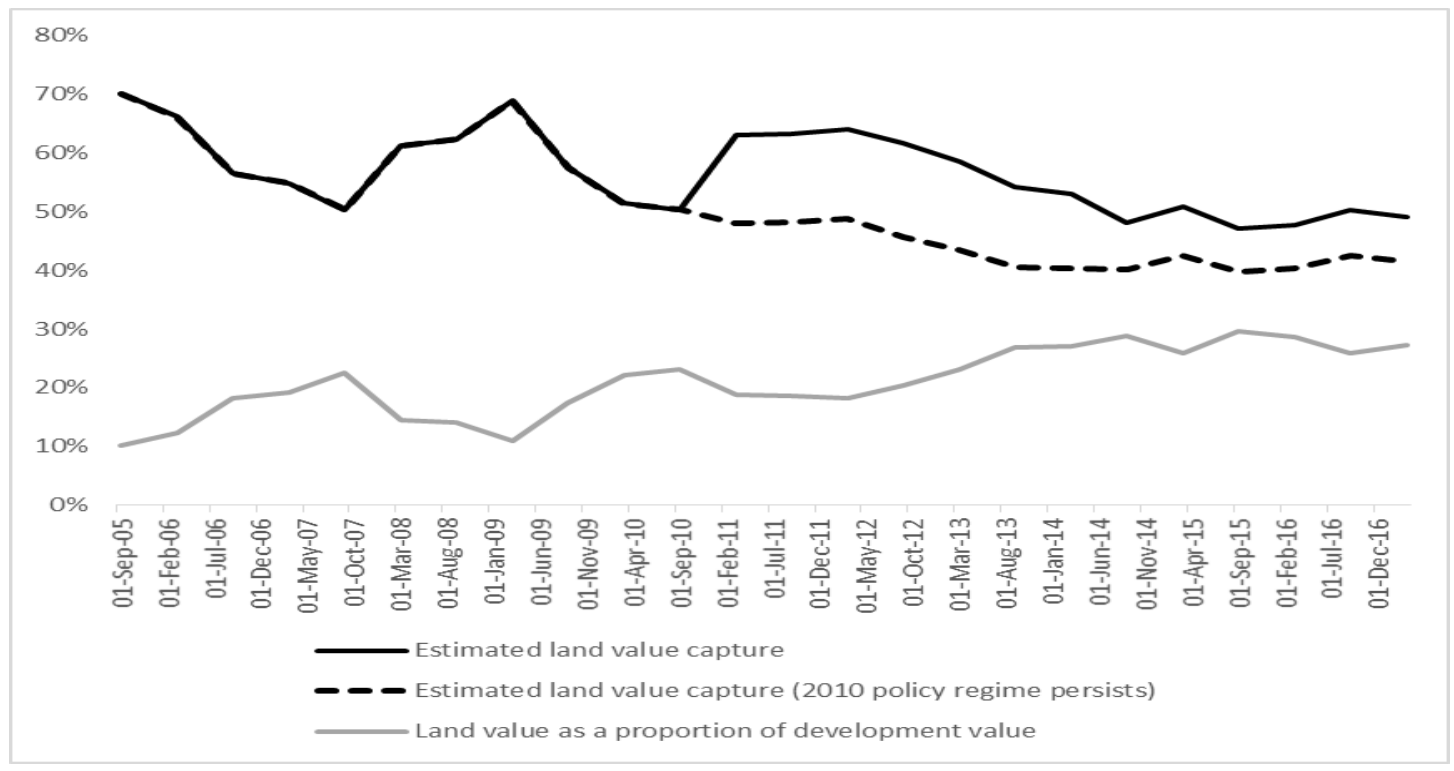


at the beginning of the period from just over $£ 7.5$ million per hectare to $£ 21$ million in September, 2007. However, in 2008 the financial crisis caused estimated land values to decline sharply to approximately $£ 9$ million per hectare in March 2009. The main determinants here were a fall in house prices and an increase in the developers' required return/profit margin to reflect perceived increased development risk. By March 2010, as house prices recovered to pre-crisis levels and construction costs fell during the market downturn, the estimated land value returned to the pre-crisis level. Between 2010 and 2012, house prices experienced rises and falls and land values experienced another decrease from c£22 million per hectare to $c £ 18$ million per hectare.

However, this fall is mainly driven by the assumption that the withdrawal of grant funding results in non-market housing providers paying developers $30 \%$ of the market value of non-market housing; this is lower than the 50\% assumed in the period 2005-2010. So, whilst the proportion of non-market housing declined to 28\% in the period March 2011 to March 2014, the positive revenue impact of this change is outweighed by the negative impact of reduced payments by non-market housing providers. After 2012, the estimated land value tends to continue to grow steadily with two pauses (largely due to two brief and minor falls in house prices) in early 2015 and mid-2016.

Trends in land value capture in absolute and relative terms are presented in Figures 3 and 4. The top line in Figure 3 illustrates the estimated land value assuming no developer contributions and the lower line illustrates the estimated land value with developer contributions taken into account. The difference, represented by the dark shading, is value of developer contributions over the study period. Perhaps unsurprisingly, given rising house prices, the introduction of the Mayoral CIL and the growth of commuted payments, the absolute amount of land value capture has increased significantly.

However, the relative proportion of land value capture decreased from $70 \%$ to $49 \%$ due to changes in market conditions and changes in the policy regime for developer contributions. For instance, between September 2005 and September 2007, without any change in the assumed developer contributions, estimated relative land value capture decreased from $70 \%$ to $50 \%$ due to rapidly rising house prices during this period. For land value capture to have remained at $70 \%$, the proportion of non-market housing needed to increase. For example, in 2017, the non-market housing proportion required to maintain relative land value capture at $70 \%$ would have been $39 \%$ whereas, based on London Development Database data, the actual average non-market housing proportion in 2017 was $25 \%$.

In Figure 4, the dotted line shows that the estimated proportion of land value capture would have decreased had the assumptions regarding developer contributions for 2005-2010 remained constant over the study period. The result is surprising because, as argued above, planning policy since 2010 has been quite hostile to the delivery of non-market housing through S106 agreements, resulting in a decline 
in the proportion of non-market housing typically agreed and a shift to more market-driven types of non-market housing. Both effects would be expected to have a negative impact on land value capture. However, withdrawal of grant subsidy (and consequent reductions in payments by non-market housing providers), increases in commuted payments and the introduction of the Mayoral CIL have actually increased land value capture from developer contributions relative to the pre-2010 land value capture regime, although the overall proportion of land value capture by the community has still decreased over the study period. The lower line in Figure 4 shows an upward trend in the proportion of land value in the overall project value over the study period. Between 2005 and 2010, estimated land costs would have typically accounted for $10 \%-20 \%$ of the total costs of the hypothetical development project. ${ }^{10}$ After 2010, this figure increased to 20\%-30\%. This is because the rate of construction cost inflation has been well-below the rate of house price inflation. Since developer contributions have not increased sufficiently to capture the increases in land value and developers' required rates of return have remained relatively stable, land owners have been capturing an increasing proportion of the land value uplift realisable upon the grant of planning permission.

Given the predominance of non-market housing as the main mechanism of land value capture, the impact of different assumptions regarding the prices paid to developers by Registered Providers on levels of land value capture are tested below. Put simply, the less that a Registered Provider pays for a unit, the higher is the land value capture. The core estimate was that Registered Providers paid on average $50 \%$ of the value of non-market unit prior to 2010 reducing to $30 \%$ post-2010 as grant funding was withdrawn, prices recovered and increased and tenure mix changed. However, as discussed above, estimating typical or average discounts for non-market housing is complex given the variety of tenures, large price variations between affluent and less affluent areas and changes in the business models of housing associations. Table 5 sets out how the proportion of land value captured would have changed using different assumptions regarding average prices paid by Registered Providers.

Table 5: $\quad$ Land Value Capture and Affordable Housing Discounts

\begin{tabular}{|c|c|c|c|}
\hline & Base scenario & High discount scenario & Low discount scenario \\
\cline { 2 - 4 } Period & $\begin{array}{c}50 \% \text { discount pre-2010 } \\
70 \% \text { discount post-2010 }\end{array}$ & $\begin{array}{c}60 \% \text { discount pre-2010 } \\
80 \% \text { discount post-2010 }\end{array}$ & $\begin{array}{c}30 \% \text { discount pre-2010 } \\
50 \% \text { discount post-2010 }\end{array}$ \\
\hline Whole period & $56.69 \%$ & $61.87 \%$ & $38.70 \%$ \\
\hline $2005-2010$ & $59.91 \%$ & $66.92 \%$ & $37.35 \%$ \\
\hline $2010-2017$ & $54.39 \%$ & $58.27 \%$ & $39.66 \%$ \\
\hline
\end{tabular}

It is apparent that the estimated proportion of land value capture is sensitive to this assumption. Compared to the central estimate that a Registered Provider paid on average 50\% of the Market Value

\footnotetext{
${ }^{10}$ Bear in mind that total project costs (including land, construction. fees, taxes and return to developer) should be equal to total project value.
} 
pre-2010 and 30\% of Market Value post-2010, when it is assumed that Registered Providers have paid $70 \%$ of Market Value pre-2010 and 50\% of Market Value post 2010, there is a substantial fall in the estimate of land value capture in relative terms. In 2017 the land value capture for the baseline scenario is $49.1 \%$. In the high discount scenario where Registered Providers are assumed to be able to acquire units at large discounts (paying 20\% of Market Value), the estimated proportion of land value capture in 2017 is just over 52\%. However, in the low discount scenario where it is assumed that Registered Providers acquire units at 50\% of Market Value, the comparable figure for relative land value capture in 2017 is approximately $35 \%$.

\section{Conclusion}

The growing political salience of housing supply and affordability have stimulated interest in land value capture. In London, developer contributions have been an important mechanism used by local government to capture land value. The key developer contribution has been 'in kind' provision nonmarket housing. Following the change in government in 2010, there seemed to be a broad policy prejudice against non-market housing. This manifested itself in: reduced subsidies to non-market housing providers; new market-orientated tenures; the introduction of permitted development rights and other exemptions for developers from requirements to deliver non-market housing; the growth of viability testing (and its specific 'targeting' of non-market housing developer contributions); and the introduction of CIL. These were expected to and are claimed to be reducing land value capture for nonmarket housing.

However, this 'policy prejudice' has evolved during a period when house prices have risen at a higher rate than construction costs and, consequently, land values have increased at a much higher rate than residential values. Land now represents a much higher proportion of development costs and provides an opportunity for increased land value capture in absolute terms. But this is an opportunity that has not been taken. In our sample of residential schemes, the proportion of non-market housing has drifted downwards from a third in 2006-2010 to a quarter in 2014-2017. Payments to developers by nonmarket housing providers (typically housing associations) for non-market housing have tended to decrease in relative terms. In particular, the withdrawal of grant subsidy in 2010, can be interpreted as a withdrawal of subsidy to land owners.

Using a land valuation methodology which attempts to mimic the land pricing methods of real estate developers, we have modelled the effects of these market changes and alterations in the funding and policy environment for land value capture on a hypothetical site in inner London over the period 2005 to 2017. The main conclusion is that the extent of land value capture in London has been relatively high. With a declining trend over the study period, approximately half the 'no developer contributions' 
land value has been captured, mainly via non-market housing provision. As residential prices have increased, the absolute amount of land value capture through developer contributions has increased, yet the proportion captured decreased. The application of land value capture policy was not revised to keep pace with increases in residential values relative to non-land development costs. Consequently, a declining proportion of land value was captured over the study period. The nature and extent of this decline depends on the prices paid by Registered Providers for non-market housing and the tenure mix of this housing.

The second conclusion is that based on the model estimates the absolute amount of land value capture has been higher than would have been the case if the policy changes had not been introduced after 2010 . Even though some of the policy changes should have had a negative impact on land value capture (Vacant Building Credit, viability testing, etc.), the effect seems to have been offset by the withdrawal of capital grant funding for non-market housing, the introduction of the affordable rent tenure, the rapid growth in residential values relative to non-market housing providers capacity to pay, increases in commuted payments in lieu of direct provision and the introduction of the Mayoral CIL. The problem of "leakage" of public subsidy to land prices is well illustrated here (Jefferys and Lloyd, 2017)

Localised land value capture in the UK is a complex process involving elements of both 'compensation' for any negative externalities generated by new development and the provision of gains to the community in the form of non-market housing, infrastructure and other public and merit goods. It is affected by numerous policy and market factors. This paper has attempted to identify trends in relative and absolute land value capture through developer contributions in inner London. However, the approach adopted is prone to uncertainty and there is a risk of over-generalisation. Furthermore, whilst some national real estate taxes such as land transfer taxes are incorporated in the land pricing model, the extent of land value capture by other direct and indirect taxes could also be considered. This would be a fruitful avenue for further research. 


\section{References}

Been, V., 2005. Impact fees and housing affordability. Cityscape, 139-185.

BNP Paribas, 2009. Affordable Housing Viability Study. Prepared for London Borough of Tower Hamlets

Bowers, J., 1992. The economics of planning gain: a re-appraisal. Urban Stud., 29 (8), 1329-1339.

Box, G. E., 1976. Science and statistics. J Am Stat Assoc, 71 (356), 791-799.

Burge, G., 2014. The capitalization effects of school, residential, and commercial impact fees on undeveloped land values. Reg Sci Urb Econ, 44, pp.1-13.

Crook, T., Henneberry, J., Rowley S., \& Watkins C. with the Halcrow Group (2006), Valuing Planning Obligations in England London Communities \& Local Government.

Crook, T., Henneberry, J., Rowley S., Smith, R. \& Watkins, C. (2008) Valuing Planning Obligations in England; Update Study London Communities \& Local Government.

Crook, T., Dunning, R., Ferrari, E., Henneberry, J., Rowley, S., Watkins, C., Burgess, G., Lyall-Grant F., Monk, S., \& Whitehead, C. (2010) The Incidence, Value and Delivery of Planning Obligations in England in 2007-08, London Communities \& Local Government.

Crook, A. T. D., Whitehead, C. M., 2002. Social housing and planning gain: is this an appropriate way of providing affordable housing? Environ. Plann. A 34 (7), 1259-1279.

Crook, T., Monk, S., 2011. Planning gains, providing homes. Hous Stud., 26 (7-8), 997-1018.

Crosby, N., Wyatt, P., 2016. Financial viability appraisals for site-specific planning decisions in England. Environ. Plann. C, 34 (8), 1716-1733.

Davis, M. A., Heathcote, J., 2007. The price and quantity of residential land in the United States. J. Mon Econ, 54 (8), 2595-2620.

Davis, M. A., Palumbo, M. G., 2008. The price of residential land in large US cities. J. Urban Econ. 63(1), 352-384.

DCLG (Department for Communities and Local Government) 2012. The National Planning Policy Framework. DCLG.

DCLG (Department for Communities and Local Government) 2014. Guidance - viability. Online. Available at: https://www.gov.uk/guidance/viability [Accessed 7 September 2017]

DCLG (Department for Communities and Local Government) 2017. Fixing our broken housing market (cm 9352). London: TSO.

DWP (Department for Work and Pensions) 2015. Welfare reform and work bill: Impact assessment of social rent reductions. 28 September 2015.

EGi 2016a. London Residential Market Analysis: Social Housing, PD Rights, Student Housing, PRS.

EGi 2016b. London Residential Market Analysis: Small Schemes

Evans-Cowley, J. S., Forgey, F. A., Rutherford, R. C., 2005. The effect of development impact fees on land values. Growth Change, 36 (1), 100-112. 
Greater London Authority, 2016. London Industrial Land Supply and Economy 2015

Greater London Authority, 2016. Tax Trial: A Land Value Tax for London

Greater London Authority, 2017. Land Value Capture: Final Report

HCA (Homes and Communities Agency) 2011. 2011-15 Affordable Homes Programme - Framework. London: HCA.

HCA (Homes and Communities Agency) 2014. Affordable Homes Programme 2015 - 2018 Prospectus. London: HCA.

HCA (Homes and Communities Agency) 2017. 2016 Global Accounts of Private Registered Providers. London: HCA.

HM Treasury 2010. Spending Review 2010 (Cm 7942). London: TSO.

Hurd, R., 1903. Principles of City Land Values.

Ihlanfeldt, K. and Shaughnessy, T., 2004. An empirical investigation of the effects of impact fees on housing and land markets. Reg Sci Urb Econ 34(6), 639-661.

Jefferys, P., Lloyd, T., 2017. Rediscovering our tradition of building beautiful and affordable homes: policy briefing

Keogh, G., 1985. The economics of planning gain. In Land Policy: Problems and Alternatives, Barrett, S and Healey, P (eds) 203-228.

Keogh, G., Evans, A. W., 1992. The private and social costs of planning delay. Urban Stud, 29 (5), 687 699.

Lewis, B., 2014. House of Commons: Written statement (HCWS50). 28 November 2014.

Mills, E. S., 1972. Urban Economics.

National Audit Office (NAO) 2012. Financial viability of the social housing sector: The launch of the Affordable Housing Programme. London: The Stationery Office.

University of Reading, Three Dragons, Hives Planning, David Lock Associates and DLA Piper LLP (2014), Section 106 Planning Obligations in England, 2011-12, London: Ministry of Housing, Communities and Local Government

Wainwright, O., 2015. Revealed: how developers exploit flawed planning system to minimise affordable housing. The Guardian, 25 June 2015.

Wetzstein, S., 2017. The global urban housing affordability crisis. Urban Stud, 54(14), 3159-3177.

Wilcox, S., Perry, J., Stephens, M., Williams, P., 2016. UK Housing Review 2016. Chartered Institute of Housing.

Wilcox, S., Perry, J., Stephens, M., Williams, P., 2017. UK Housing Review 2017. Chartered Institute of Housing.

Wilson, W., Bate, A., 2015. Affordable rents (England) (House of Commons Briefing Paper 05933). House of Commons Library. 
Appendix 1: Inner London Non-Market Housing Evidence on Discounts for Registered Providers from Viability Studies

\begin{tabular}{|c|c|c|c|}
\hline Local Authority & Year & Type of study & Discount from Market Value for non-market housing \\
\hline Camden & 2009 & $\begin{array}{l}\text { Affordable Housing Viability } \\
\text { Assessment }\end{array}$ & $\begin{array}{l}\text { Social Rent: average discount of } 40 \% \text {. } \\
\text { Shared Ownership: average discount of } 20 \% \text { discount. }\end{array}$ \\
\hline Islington & 2009 & $\begin{array}{l}\text { Affordable Housing Viability } \\
\text { Assessment }\end{array}$ & $\begin{array}{l}\text { Social Rent: average discount of } 65 \% \text { (range of } 33 \%-76 \% \text { ) } \\
\text { Shared Ownership: average discount of } 62 \% \text { (range of } 29 \%-74 \% \text { ) }\end{array}$ \\
\hline Tower Hamlets & 2009 & $\begin{array}{l}\text { Affordable Housing Viability } \\
\text { Assessment }\end{array}$ & $\begin{array}{l}\text { Social Rent: average discount of } 56 \% \text { (range of } 20 \%-70 \% \text { ) } \\
\text { Shared Ownership: average discount of } 51 \% \text { (range of } 10 \%-67 \% \text { ) }\end{array}$ \\
\hline Hackney & 2010 & $\begin{array}{l}\text { Affordable Housing Viability } \\
\text { Assessment }\end{array}$ & $\begin{array}{l}\text { Social Rent: average discount of } 81 \% \text { (range of } 77 \%-85 \% \text { ) } \\
\text { Shared Ownership: average discount of } 49 \% \text { (range of } 37 \%-58 \% \text { ) }\end{array}$ \\
\hline Southwark & 2010 & $\begin{array}{l}\text { Affordable Housing Viability } \\
\text { Assessment }\end{array}$ & $\begin{array}{l}\text { Overall average discount of } \mathbf{3 2} \% \text {. } \\
\text { Study carried out before the General Election in } 2010 .\end{array}$ \\
\hline Westminster & 2010 & $\begin{array}{l}\text { Affordable Housing Viability } \\
\text { Assessment }\end{array}$ & $\begin{array}{l}\text { Social Rent: average discount of } 60 \% \\
\text { Shared Ownership: average discount of } 40 \% \text {. }\end{array}$ \\
\hline Lewisham & 2012 & $\begin{array}{l}\text { CIL Viability } \\
\text { Appraisal }\end{array}$ & $\begin{array}{l}\text { Social Rent: average discount of } 81 \% \text { (range of } 74 \%-85 \% \text { ) } \\
\text { Affordable Rent: average discount of } 64 \% \text { (range of } 51 \%-71 \% \text { ) } \\
\text { Shared Ownership: average discount of } 37 \% \text { (range of } 15 \%-50 \% \text { ) }\end{array}$ \\
\hline City of London & 2013 & $\begin{array}{l}\text { Community Infrastructure } \\
\text { Levy: Economic Viability Study }\end{array}$ & Overall average discount of over $80 \%$. \\
\hline Tower Hamlets & 2013 & CIL Viability study & Overall average discount of $c 62 \%-72 \%$. \\
\hline Wandsworth & 2013 & $\begin{array}{l}\text { Affordable Housing Viability } \\
\text { Assessment }\end{array}$ & $\begin{array}{l}\text { Social Rent: average discount of } 80 \% \text { (range of } 58 \%-87 \% \text { ) } \\
\text { Shared Ownership: average discount of } 64 \% \text { (range of } 25 \% \text { - } 76 \% \text { ) }\end{array}$ \\
\hline $\begin{array}{l}\text { Hammersmith and } \\
\text { Fulham }\end{array}$ & 2014 & CIL Viability study & Overall average discounts range from $50 \%-75 \%$. \\
\hline
\end{tabular}




\begin{tabular}{|c|c|c|c|}
\hline Camden & 2015 & $\begin{array}{l}\text { London Borough of Camden } \\
\text { Local Plan Review } \\
\text { Evidence Base: Financial } \\
\text { Viability Study }\end{array}$ & $\begin{array}{l}\text { Social Rent: average discount of } 88 \% \text { (range of } 91 \%-85 \% \text { ) } \\
\text { Affordable Rent: average discount of } 76 \% \text { (range of } 82 \%-72 \% \text { ) } \\
\text { Shared Ownership: average discount of } 72 \%-88 \% \text { depending on income threshold (range } \\
\text { of } 64 \%-86 \% \text { ) }\end{array}$ \\
\hline Camden & 2015 & Review of Evidence Base for CIL & $\begin{array}{l}\text { Social Rent: average discount of } 84 \% \text { (range of } 85 \%-83 \% \text { ) } \\
\text { Shared Ownership: average discount of } 77 \% \text { (range of } 82 \%-71 \% \text { ) }\end{array}$ \\
\hline Haringey & 2015 & $\begin{array}{l}\text { Site Allocation Viability } \\
\text { Assessment }\end{array}$ & $\begin{array}{l}\text { Social Rent: average discount of } 73 \% \text { (range of } 80 \%-66 \% \text { ) } \\
\text { Shared Ownership: average discount of } 40 \% \text { (range of } 66 \% \text { - 14\%) }\end{array}$ \\
\hline Southwark & 2015 & $\begin{array}{l}\text { Internal review of submitted } \\
\text { viability studies }\end{array}$ & Overall average discount of $77 \%-40 \%$. \\
\hline Southwark & 2015 & $\begin{array}{l}\text { Affordable Housing Viability } \\
\text { Assessment }\end{array}$ & Overall average discount of $c 75 \%$ \\
\hline $\begin{array}{l}\text { Hammersmith and } \\
\text { Fulham }\end{array}$ & 2016 & $\begin{array}{l}\text { Affordable Housing Viability } \\
\text { Assessment }\end{array}$ & $\begin{array}{l}\text { Social Rent: average discount of } 90 \% \\
\text { Shared Ownership: average discount of } \mathbf{7 2 \%}\end{array}$ \\
\hline $\begin{array}{l}\text { Royal Borough of } \\
\text { Kensington and } \\
\text { Chelsea }\end{array}$ & 2017 & $\begin{array}{l}\text { Affordable Housing Viability } \\
\text { Assessment }\end{array}$ & Shared Ownership: average discount of $70 \%$ in low value area \\
\hline
\end{tabular}

There is also evidence to suggest that there was a substantial increase in payments in lieu of non-market housing over the study period. EGi (2016a) found that in the period 2004-2015 just over $£ 1$ billion was agreed in in lieu payments. In the period 2004-2010, total commuted payments for London were between $£ 10$ million and $£ 20$ million per annum. This increased substantially to c£200 million in 2011 peaking at $£ 320$ million in 2015 . The evidence suggests that commuted payments "varied wildly" from borough to borough with some local planning authorities being much more receptive to off-site provision of nonmarket housing and/or commuted payments compared to others (EGi, 2016b). Whilst the evidence from London Development Database is not complete in this topic, it is consistent with a substantial majority of the commuted sums being paid in Westminster and the Royal Borough of Kensington and Chelsea. Based on the data concerning the number and scale of permitted space and the amounts of commuted payments, an allowance of $£ 25$ per square metre of space developed is made for in lieu payments in the period 2004-2010. This is increased to £150 per square metre of space developed in the period 2011-2017. In some cases, a commuted payment may be made in lieu of the direct provision of any non-market housing. In other cases, a combination of a commuted payment and direct provision of non-market housing may be agreed. In addition, clawback clauses associated with viability tests increasingly include provisions for a cash payment (a deferred affordable housing contribution) to the local planning authority if realised post-development revenues or returns to the developer are above a certain threshold. In the land valuation model, it is assumed that the developer contribution approximates to the estimated average level of non-market housing provision and the average level of commuted payment. 